Biological and Clinical Sciences Research Journal

ISSN: 2708-2261

www.bcsrj.com

DOI: https://doi.org/10.54112/bcsri.v2020i1.38

Biol. Clin. Sci. Res. J., Volume, 2020: 38

Original Research

\title{
GENETIC EVALUATION FOR SEEDLING TRAITS OF MAIZE AND WHEAT UNDER BIOGAS WASTEWATER, SEWAGE WATER AND DROUGHT STRESS CONDITIONS
}

\author{
BALQEES N, *ALI Q, MALIK A \\ Institute of Molecular Biology and Biotechnology, The University of Lahore, Lahore, Pakistan \\ *Corresponding author email: saim1692@gmail.com
}

(Received, $12^{\text {th }}$ June 2020, Revised $5^{\text {th }}$ November 2020, Published $14^{\text {th }}$ November 2020)

\begin{abstract}
Cereals grains have feed mankind since their domestication thousands of years ago and remained the most important source of calories for the majority of human population. Wheat (Triticum aestivum L.) and Maize (Zea mays L.) are used as staple food for more than 50\% of world population. For evaluation of wheat and maize genotype under biogas wastewater, sewage water and drought stress, an experiment was conducted in the greenhouse of Institute of Molecular Biology and Biotechnology, The University of Lahore, Lahore, Pakistan. The treatments of biogas wastewater, sewage water and drought for maize and wheat genotypes were kept as following T1: control (normal irrigation condition) $T_{2}$ (sewage water $100 \mathrm{ml}$ ), $T_{3}$ (biogas wastewater $100 \mathrm{ml}$ ), $T_{4}$ (drought $75 \%$ (25ml water)), $T_{5}$ (biogas $150 \mathrm{ml}$ ) and $T_{6}$ (sewage water $150 \mathrm{ml}$ ) respectively). It was observed from the results that the performance of maize and wheat genotypes were highly variable under biogas wastewater, sewage water and drought treatments. The treatment of sewage water $(150 \mathrm{ml})$ and drought $(75 \%)$ were found as the higher toxic treatments of maize and wheat which were predicted as they may cause to decrease in the photosynthetic rate, productivity and growth of plants. The significant correlation was found between root length and shoot length for both of the genotypes. It was found from the results that maize genotype (Raka-poshi) performed better under most of the stress treatments as compared with wheat genotype (Galaxy-2013) while the higher genetic advance and heritability were reported for maize genotype which revealed that the maize may used to grow for higher grain production under biogas wastewater, sewage water and drought stress conditions.
\end{abstract}

Keywords: menthol, maize, wheat, cereals, drought, genetic advance, heritability

\section{Introduction}

Cereals grains have nourished humanity since their domestication thousands of years ago and remained the most important source of calories for the majority of human population. Three major cereal grains i.e., maize, wheat and rice and other minor grains e.g., barley, sorghum, oat, rye, millet provided about $56 \%$ of the food energy and $50 \%$ of the protein consumed on earth (Frassetto et al., 2001; Simopoulos, 1999). Wheat and maize are one of the major cereal plants on this planet which provide food for human and animals as well (Jat et al., 2012; Majumdar et al., 2013). Maize is one of the highest ranking crops in the globe. It is produced in 94 developing countries. It provides 4.3 billion people at least $30 \%$ of food calories in 94 emergent nations. About $67 \%$ of total maize production comes from low and lower middle income countries hence it is important role in the livelihood of millions of farmers. Maize is also essential in animal feed and is widely used in industrial products including the manufacture of biofuels. The increasing production and demand shortfalls in world maize supplies have down market volatility and contributed to surgical world maize prices (FAOSTAT, 2017). In 2019, demand rose to 766 million tons making it the second most important food crop. Drought is a natural hazard which intensifies the water scarcity and brings significantly adverse impacts on global economy. Global warming, irregular and insufficient patterns of rainfalls and un-judicious use of water resources are the leading causes of soil water deficit (Lal, 2004; Rosegrant and Cline, 2003). It is a worldwide problem, which has confined the quality and productivity of crops. Out of 1474 million ha cultivated land of world, $86 \%$ area comes under rain fed cultivation (Hurd, 1976; Terán and Singh, 2002). Wheat is a staple food of about $35 \%$ population of world. There is an elevation in demand for wheat production due to exponentially increasing human population. Under extreme climatic conditions, current rate of wheat production is not sufficient to fulfill food demands of the world due to limited irrigation resources and low ground water table (Moaveni, 2011; Yan, 2015). Furthermore, rapid increase in population growth, urbanization, industrialization and agricultural development has

[Citation: Balqees, N., Ali, Q., Malik, A. (2020). Genetic evaluation for seedling traits of maize and wheat under biogas wastewater, sewerage water and drought stress conditions. Biol. Clin. Sci. Res. J., 2020: 38 . doi: https://doi.org/10.54112/bcsrj.v2020i1.38] 
increased country's water requirement. Pakistan has diverse climatic conditions and two-third of the land area lies in semi-arid and arid climate regions (Adnan et al., 2017; Chaudhry and Rasul, 2004; Iqbal et al., 2016). Wheat is one of the oldest and most important of the cereal crops. A lot of species are known, but the most important are common wheat (Triticum aestivum), used to make bread; durum wheat ( $T$. durum), used in making pasta (alimentary pastes) such as spaghetti and macaroni; and club wheat ( $T$. compactum), a softer type, used for cake, crackers, cookies, pastries, and flours. Additionally, some wheat species are used by industry for the production of starch, paste, malt, dextrose, gluten, alcohol, and other products. Wheat is used as livestock feed, as human food, as biofuel, and as raw material in industry. Wheat is the major staple food as in the Agricultural and governmental policies with a per capita utilization of about $125 \mathrm{Kg}$ to $130 \mathrm{~kg}$; wheat occupies a central role (Neves et al., 2017; Raza et al., 2019; Salehi-Lisar and Bakhshayeshan-Agdam, 2016). The present study was conducted to evaluate the effects of drought, biogas waste water and sewage water on the seedling growth traits of wheat and maize under greenhouse conditions.

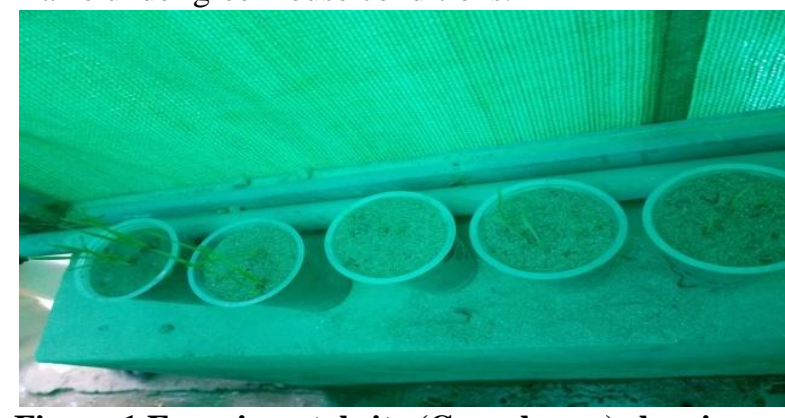

Figure 1 Experimental
Results and discussion

During our study we have applied different treatments on wheat and maize genotypes which showed different effects through change in their morphological seedling traits. The results showed that the coefficient of variance was found lower for all studied traits of wheat and maize which revealed the consistency of results for all traits in maize and wheat (Table 1). It was found from mean comparison between maize and wheat genotypes that there was better performance of maize genotype Raka-poshi under the effects of all applied treatments as compared with wheat (Figures 2-6). The results from figures for all studied traits indicated that the applications of treatments showed not good even toxic effects for wheat genotype which may become the cause to decrease photosynthetic rate, growth and

\section{Materials and methods}

For evaluating maize and wheat genotype for biogas wastewater, sewage water as well as drought stress the present research experiment was conducted in the greenhouse (Figure 1) of Institute of Molecular Biology and Biotechnology, The University of Lahore, Lahore. The seeds of selected genotypes of maize and wheat were sown in 36pots, 18 pots for each crop. The pots were filled with the layers of pure sand. The treatments of biogas wastewater, sewage water and drought for maize and wheat were kept as following: $T_{1}$ control (normal irrigation condition), $\mathrm{T}_{2}$ biogas wastewater $(100 \mathrm{ml}), \mathrm{T}_{3}$ (sewage water $(100 \mathrm{ml}), \mathrm{T}_{4}$ drought $(75 \%(25 \mathrm{ml}$ water was applied as compared with normal $200 \mathrm{ml}$ water)), $\mathrm{T}_{5}$ biogas wastewater $(150 \mathrm{ml})$ and $\mathrm{T}_{6}$ sewage water (150ml). Treatments of each stress were given after 7 days of germination of maize and wheat seedlings. Treatments were applied 4 times and data was recorded after application of each time of treatment. The seedling data was recorded for these traits included leaf length, leaf width, roots per plant, root length and shoot length. The recorded data was analyzed statistically through analysis of variance (ANOVA) techniques by using SPSS23.1 software.

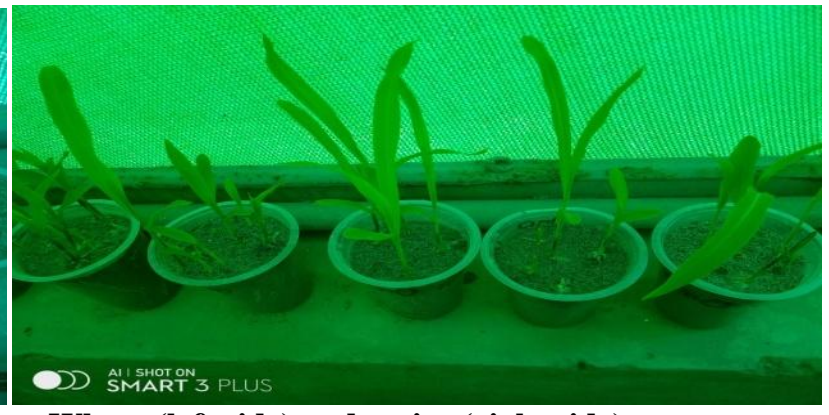

ots Wheat (left side) and maize (right side)

development of plant under different stressful conditions (Ali et al., 2017; Ali et al., 2013; Efeoğlu et al., 2009; Zubair et al., 2016). The results from table 1 showed that the genetic advance for leaf length was found higher for Raka-poshi $(15.35 \%)$ as compared with Galaxy-2013 (14.325\%), for leaf width $(21.234 \%, 17.67 \%)$, root length $(20.457 \%$, $16.98 \%)$, shoot length $(21.045 \%, 22.084 \%)$ and roots per plant $(19.245 \%, 17.258 \%)$ for Raka-poshi and Galaxy-2013 respectively. The heritability for leaf length was found higher for Raka-poshi $(89.43 \%)$ as compared with Galaxy-2013 (88.89\%), for leaf width $(90.87 \%, 90.32 \%)$, root length $(91.422 \%, 89.67 \%)$, shoot length $(92.452 \%, 91.244 \%)$ and roots per plant $(91.002 \%, 90.245 \%)$ for Raka-poshi and Galaxy2013 respectively. It was found that (maize genotype) performed better under all stress treatments for

[Citation: Balqees, N., Ali, Q., Malik, A. (2020). Genetic evaluation for seedling traits of maize and wheat under biogas wastewater, sewerage water and drought stress conditions. Biol. Clin. Sci. Res. J., 2020: 38. doi: https://doi.org/10.54112/bcsrj.v2020i1.38] 
seeding traits while higher genetic advance of shoot length was found for wheat as compared to maize genotype (Ahsan et al., 2013; Ali et al., 2016; Ali et al., 2014). The higher genetic advance indicated that the selection of maize and wheat genotypes for the improvement of grain yield may be helpful while on the basis of shoot length, root length and number of roots per plant (Betran et al., 2003; Beyene et al., 2015; Zhu et al., 2012).

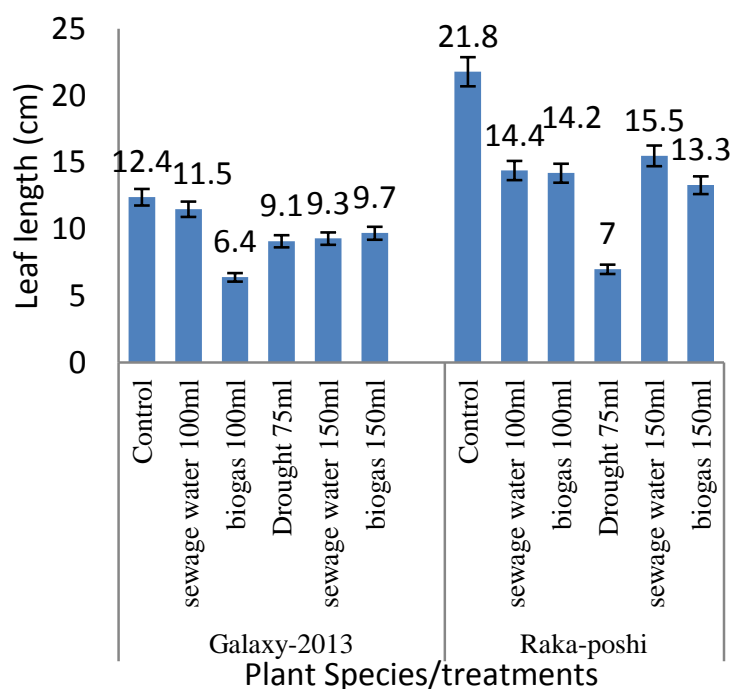

Figure 2. Leaf length of maize and wheat genotype under different treatments

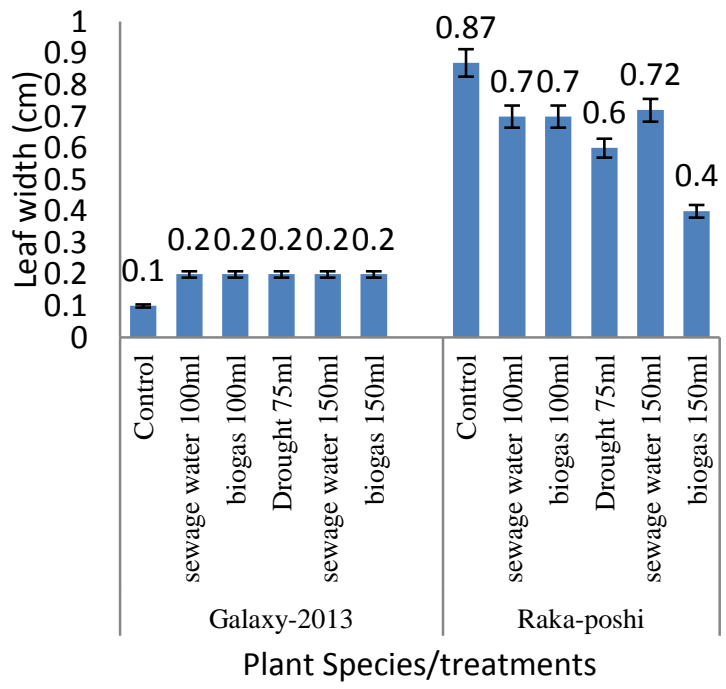

Figure 3. Leaf width of maize and wheat genotype under different treatments

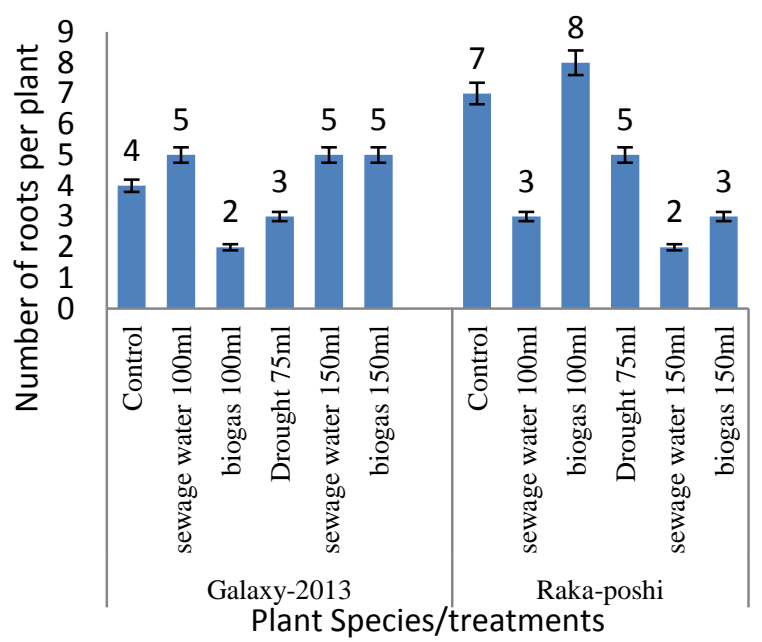

Figure 4. Number of roots per plant of maize and wheat genotype under different treatments

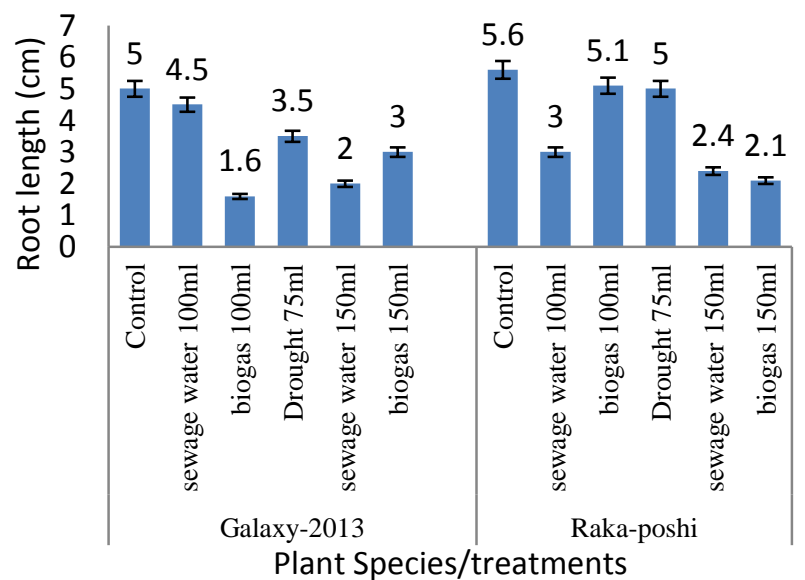

Figure 5. Root length of maize and wheat genotype under different treatments

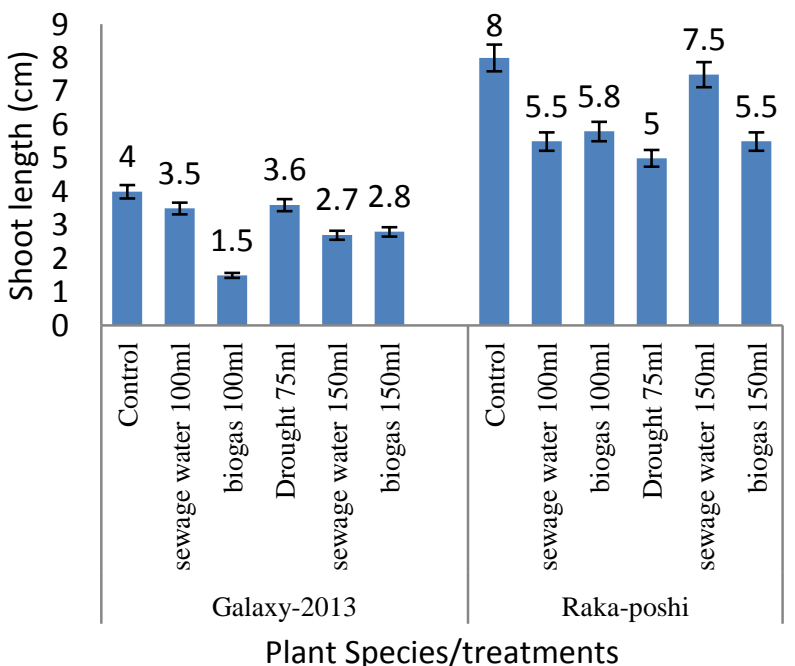

Figure 6. Shoot length of maize and wheat genotype under different treatments

[Citation: Balqees, N., Ali, Q., Malik, A. (2020). Genetic evaluation for seedling traits of maize and wheat under biogas wastewater, sewerage water and drought stress conditions. Biol. Clin. Sci. Res. J., 2020: 38 . doi: https://doi.org/10.54112/bcsrj.v2020i1.38] 
Table 1. Genetic components for different traits of maize and wheat under different treatments

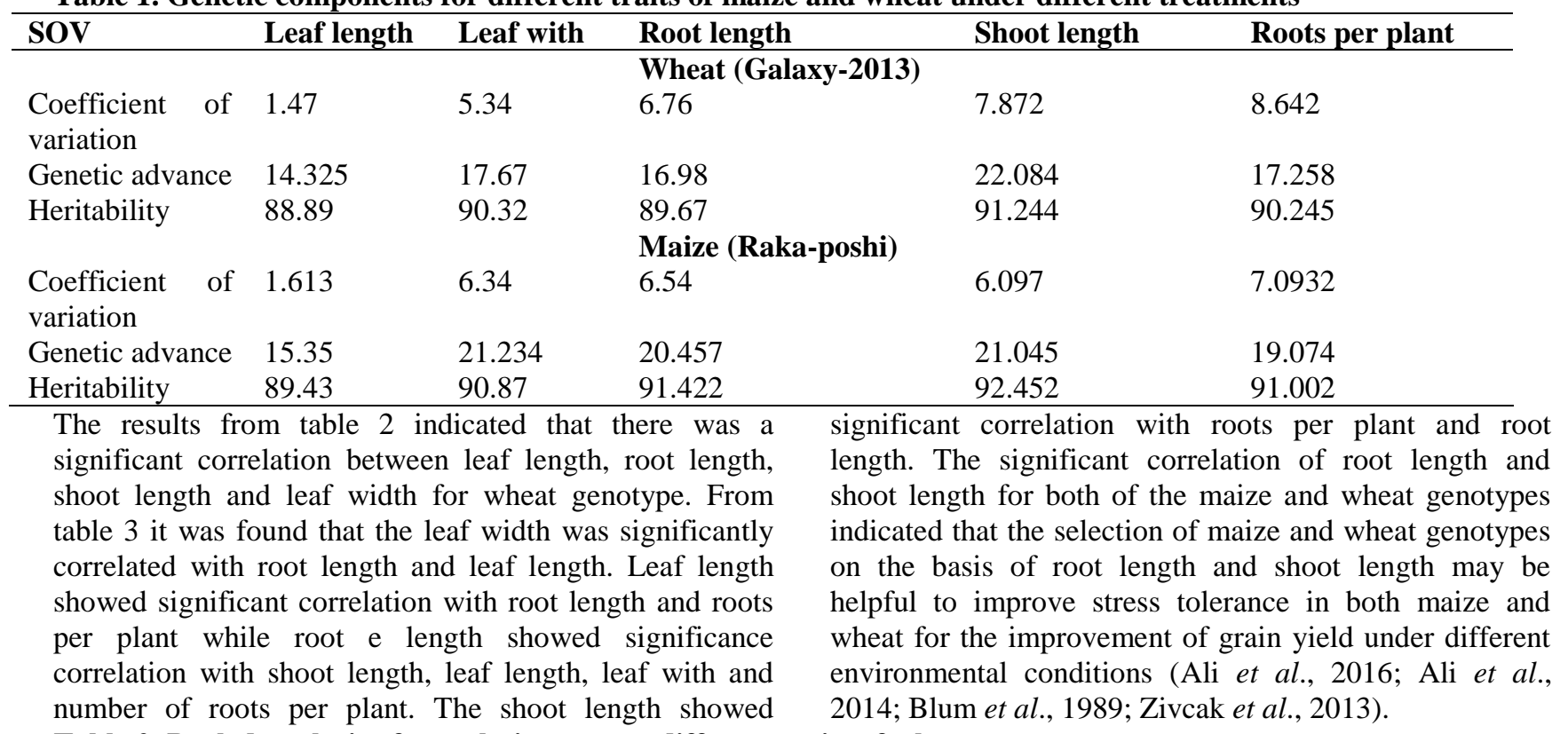

Table 2. Pooled analysis of correlation among different traits of wheat

\begin{tabular}{|c|c|c|c|c|}
\hline Traits & Leaf width & Leaf length & Root length & Shoot length \\
\hline Leaf length & $0.6274 *$ & & & \\
\hline Root length & $0.5452 *$ & 0.0234 & & \\
\hline Shoot length & $0.4246^{*}$ & 0.1240 & $0.4917 *$ & \\
\hline Roots per plant & 0.1392 & $0.4123^{*}$ & $0.3291 *$ & $0.3151 *$ \\
\hline
\end{tabular}

Table 3. Pooled analysis of correlation among different traits of maize

\begin{tabular}{lllll}
\hline Traits & Leaf width & Leaf length & Root length & Shoot length \\
\hline Leaf length & $0.4920^{*}$ & & & \\
Root length & $0.3128^{*}$ & $0.4932^{*}$ & & \\
Shoot length & 0.2046 & 0.1001 & $0.4017^{*}$ & $0.4514^{*}$ \\
Roots per plant & 0.0122 & $0.3083^{*}$ & $0.5011^{*}$ & 0.45 probability level \\
\hline
\end{tabular}

\section{Conclusion}

It was noticed from the results that the performance of wheat and maize genotypes was highly variable under biogas, sewage water and drought stress treatment. The treatments $150 \mathrm{ml}$ of sewage water and $75 \%$ drought stress were found as the higher toxic treatments for maize and wheat which may decrease the photosynthetic rate, productivity and development of plants. It was found from the results that maize performed better under most of the treatments as compared to wheat, however the genetic advance and heritability were found with minor differences for wheat and maize genotypes. The significant correlation was found between root length and shoot length for both of the genotypes.

Conflict of interest

The authors declared absence of any conflict of interest.

References
Adnan, S., Ullah, K., Gao, S., Khosa, A. H., and Wang, Z. (2017). Shifting of agro-climatic zones, their drought vulnerability, and precipitation and temperature trends in Pakistan. International Journal of Climatology 37, 529-543.

Ahsan, M., Farooq, A., Khaliq, I., Ali, Q., Aslam, M., and Kashif, M. (2013). Inheritance of various yield contributing traits in maize (Zea mays L.) at low moisture condition. African Journal of Agricultural Research 8, 413-420.

Ali, F., Ahsan, M., Ali, Q., and Kanwal, N. (2017). Phenotypic stability of Zea mays grain yield and its attributing traits under drought stress. Frontiers in plant science 8, 1397.

Ali, Q., Ahsan, M., Ali, F., Aslam, M., Khan, N. H., Munzoor, M., Mustafa, H. S. B., and Muhammad, S. (2013). Heritability, heterosis and heterobeltiosis studies for morphological

[Citation: Balqees, N., Ali, Q., Malik, A. (2020). Genetic evaluation for seedling traits of maize and wheat under biogas wastewater, sewerage water and drought stress conditions. Biol. Clin. Sci. Res. J., 2020: 38 . doi: https://doi.org/10.54112/bcsrj.v2020i1.38] 
traits of maize (Zea mays L.) seedlings. Advancements in Life sciences $\mathbf{1}$.

Ali, Q., Ahsan, M., Kanwal, N., Ali, F., Ali, A., Ahmed, W., Ishfaq, M., and Saleem, M. (2016). Screening for drought tolerance: comparison of maize hybrids under water deficit condition. Advancements in Life Sciences 3, 51-58.

Ali, Q., Ali, A., Ahsan, M., Nasir, I. A., Abbas, H. G., and Ashraf, M. A. (2014). Linex Tester analysis for morpho-physiological traits of Zea mays L seedlings. Advancements in Life sciences 1, 242-253.

Betran, F., Beck, D., Bänziger, M., and Edmeades, G. (2003). Genetic analysis of inbred and hybrid grain yield under stress and nonstress environments in tropical maize. Crop Science 43, 807-817.

Beyene, Y., Semagn, K., Mugo, S., Tarekegne, A., Babu, R., Meisel, B., Sehabiague, P., Makumbi, D., Magorokosho, C., and Oikeh, S. (2015). Genetic gains in grain yield through genomic selection in eight bi-parental maize populations under drought stress. Crop Science 55, 154-163.

Blum, A., Shpiler, L., Golan, G., and Mayer, J. (1989). Yield stability and canopy temperature of wheat genotypes under drought-stress. Field Crops Research 22, 289-296.

Chaudhry, Q., and Rasul, G. (2004). Agro-climatic classification of Pakistan. Science Vision 9, 5966.

Efeoğlu, B., Ekmekçi, Y., and Çiçek, N. (2009). Physiological responses of three maize cultivars to drought stress and recovery. South African Journal of Botany 75, 34-42.

FAOSTAT, I. (2017). Statistical databases and data-sets of the food and agriculture organization of the United Nations.

Frassetto, L., Morris Jr, R., Sellmeyer, D., Todd, K., and Sebastian, A. (2001). Diet, evolution and aging. European journal of nutrition 40, 200213.

Hurd, E. (1976). Plant breeding for drought resistance. In "Soil water measurement, plant responses, and breeding for drought resistance", pp. 317-353. Academic Press.

Iqbal, M. A., Penas, A., Cano-Ortiz, A., Kersebaum, K. C., Herrero, L., and del Río, S. (2016). Analysis of recent changes in maximum and minimum temperatures in Pakistan. Atmospheric Research 168, 234-249.

Jat, M., Kumar, D., Majumdar, K., Kumar, A., Shahi, V., Satyanarayana, T., Pampolino, M., Gupta, N., Singh, V., and Dwivedi, B. (2012). Crop response and economics of phosphorus fertiliser application in rice, wheat and maize in the Indo-Gangetic Plains. Indian Journal of Fertilisers 8, 62-72.

Lal, R. (2004). Soil carbon sequestration impacts on global climate change and food security. science 304, 1623-1627.

Majumdar, K., Jat, M. L., Pampolino, M., Satyanarayana, T., Dutta, S., and Kumar, A. (2013). Nutrient management in wheat: current scenario, improved strategies and future research needs in India. Journal of Wheat Research 4, 1-10.

Moaveni, P. (2011). Effect of water deficit stress on some physiological traits of wheat (Triticum aestivum). Agric. Sci. Res. J 1, 64-68.

Neves, D. M., da Hora Almeida, L. A., SantanaVieira, D. D. S., Freschi, L., Ferreira, C. F., dos Santos Soares Filho, W., Costa, M. G. C., Micheli, F., Coelho Filho, M. A., and da Silva Gesteira, A. (2017). Recurrent water deficit causes epigenetic and hormonal changes in citrus plants. Scientific reports 7, 1-11.

Raza, A., Razzaq, A., Mehmood, S. S., Zou, X., Zhang, X., Lv, Y., and Xu, J. (2019). Impact of climate change on crops adaptation and strategies to tackle its outcome: A review. Plants 8, 34.

Rosegrant, M. W., and Cline, S. A. (2003). Global food security: challenges and policies. Science 302, 1917-1919.

Salehi-Lisar, S. Y., and Bakhshayeshan-Agdam, H. (2016). Drought stress in plants: causes, consequences, and tolerance. In "Drought Stress Tolerance in Plants, Vol 1", pp. 1-16. Springer.

Simopoulos, A. P. (1999). "Evolutionary Aspects of Nutrition and Health: Diet, Exercise, Genetics, and Chronic Disease," Karger Medical and Scientific Publishers.

Terán, H., and Singh, S. P. (2002). Comparison of sources and lines selected for drought resistance in common bean. Crop Science 42, 64-70.

Yan, M. (2015). Seed priming stimulate germination and early seedling growth of Chinese cabbage under drought stress. South African Journal of Botany 99, 88-92.

Zhu, X., Song, F., Liu, S., Liu, T., and Zhou, X. (2012). Arbuscular mycorrhizae improves photosynthesis and water status of Zea mays L. under drought stress. Plant, Soil and Environment 58, 186-191.

Zivcak, M., Brestic, M., Balatova, Z., Drevenakova, P., Olsovska, K., Kalaji, H. M., Yang, X., and Allakhverdiev, S. I. (2013). Photosynthetic electron transport and specific photoprotective

[Citation: Balqees, N., Ali, Q., Malik, A. (2020). Genetic evaluation for seedling traits of maize and wheat under biogas wastewater, sewerage water and drought stress conditions. Biol. Clin. Sci. Res. J., 2020: 38 . doi: https://doi.org/10.54112/bcsrj.v2020i1.38] 
responses in wheat leaves under drought stress. Photosynthesis research 117, 529-546.

Zubair, M., Shakir, M., Ali, Q., Rani, N., Fatima, N., Farooq, S., Shafiq, S., Kanwal, N., Ali, F., and Nasir, I. A. (2016). Rhizobacteria and phytoremediation of heavy metals. Environmental Technology Reviews 5, 112-119.

\section{(c) (7) (8)}

Open Access This article is licensed under a Creative Commons Attribution 4.0 International License, which permits use, sharing, adaptation, distribution and reproduction in any medium or format, as long as you give appropriate credit to the original author(s) and the source, provide a link to the Creative Commons licence, and indicate if changes were made. The images or other third party material in this article are included in the article's Creative Commons licence, unless indicated otherwise in a credit line to the material. If material is not included in the article's Creative Commons licence and your intended use is not permitted by statutory regulation or exceeds the permitted use, you will need to obtain permission directly from the copyright holder. To view a copy of this licence, visit http://creativecommons.org/licen ses/by/4.0/.

(c) The Author(s) 2020

[Citation: Balqees, N., Ali, Q., Malik, A. (2020). Genetic evaluation for seedling traits of maize and wheat under biogas wastewater, sewerage water and drought stress conditions. Biol. Clin. Sci. Res. J., 2020: 38. doi: https://doi.org/10.54112/bcsrj.v2020i1.38] 